\title{
A Document on Peace and Protest in the Pages Stained With Blood By Indira Goswami
}

\author{
T Vanitha \\ 11/132 Pudhu Nager, Hudco Colony, Tirupur
}

\begin{abstract}
:
Indira Goswamy popularly known as MamoniRaisomGoswami an icon of Assamese Literature presents the contrasting effects of peace as well as protest in her novel pages stained with blood.It was written in Assamese and later translated by Pradip Acharya in English. Actually Goswamy desired to write a book on Delhi with its pride and pomp. She settled in a small cooped up flat in Sather nagar, Delhi. She came across a few Sikh people who helped her in one way or other. She had learnt various anecdotes about the Moghal and the British rulers. Some were tell-tale stories and some were records of the past. She even visited whores colony to collect sources for her material. Where ever she went she showed courtesy to her fellow human beings and tried to help them in all possible ways. The novel is an out pour of her bitter memories during the anti-Sikh Riots caused by the assassination of Smt. Indira Gandhi when she was the prime minister of India. Neither the politicians nor the administers bothered much about the communal calamities. Negligence of the authorities and heart rendering cry of the suppressed have left a deep scar in her heart. She is unable to accept the cruel reality. She highlights some of the good qualities of the Sikh people such as not accepting money even in their worst condition. Their sincere prayer to forgive the people who caused severe damage to Gurudwara.MadanBhaisahab's timely help to the injured are some proofs. She also presented an amazing fact that no one has touched the politician's house during the agitation.As the author feels these pages of Indian History are stained with blood. It is aneternal stain which could not be washed away.

Keywards : Indira Goswami, Chandhini Chwok-Akber's

Harem, Dastambu-stories, Brigadier Mansingh.
\end{abstract} Reference to this paper should be made as follows:

TVanitha,

A Document on Peace and Protest in the Pages

Stained With Blood By

Indira Goswami,

Notions 2018, Vol. IX, No.2, pp. 23-33, Article No. 5

Online available at : http://anubooks.com/

?page_id=34 
Indira Goswami popularly known as MamoniRaisomGoswami an icon of Assame Literature presents a nice blend of peace and protest in her novel "PAGES STAINED WITH BLOOD "It was originally written in Assame and latter translated by Pradip Acharya in English. The Assame original was serialized in the periodical GARIWOSI in 1986 with the title TEJ ARU DHULERE DHUHORITA PRISHTHA -BLOOD AND DUST-CLOTTED PAGES .In English it was translated by PradipAcharya,published by 'katha' publishers in 2002. It was title as THE PAGES STAINED WITH BLOOD .The novel appears as record of past rather than a literary master piece. Actually Goswami desired to write a book on Delhi with its pride and hues that is of the Mughals and the British.

The author settled in a small cooped up flat in SakthiNagar,Delhi. There is a place known as 'Golchakkar, a few meters away from her residence', gave her a lot of interesting informations. RoshanaraBagicha is at walkable distance from her . It is the adda of thieves and decoits. She used to go for morning walks there. The author says,

"Khusro, Ghalib,Meer,Mirza Abdul Rahim khankhana, Momin all the great shaairs were fascinated by Delhi. Delhi beckoned them all and they were enticed by her as by a mysterious and alluring courtesan who eluded their grasp and was beyond their reach. I too wanted to see and feel the Delhi of their dreams"(68)

She was fascinated by many tell tale stories narrated by BalbirSingh, the kabadiwalla.He told stories about kabadiwallas of Urdu Bazaar. The author's colleague JetlyShahab had told her an interesting story about Urdu Bazaar.JairamdasDaulatram one time Governor of Assam during his hardship stayed in the decrepit quarters on Mandir Marg.His trusted servant stole and sold some of his valuable books in the Urdu Bazaar.Balbir Singh's cucumber story is another interesting anecdote. In Urdu Bazaar places like KuchaMahajini and Dariba Kalan, the price of gold and silver has sky rocketed. Even then the people buy gold and silver. He said even today they sell four thousand kilogram's of silver every day. $f$. It was unbelievable to the author but Balbir assured it was true and their descendentsare still around. He told there were numerous stories about the sultans, Nawabs and ordinary merchants which lie buried in the heart of ChandhiniChowk.Thedescription of Akbar's Harem is another interesting document. It was described in a book given by Balbir Singh written by AbulFazalShe had read about two Majnus. One was a contemporary of GuruNanak.Hehad moved to a hillock on the bank of the Jamuna and started his meditations there. He meditated day and night. People named him Majnu.During the reign of Sikandar Lodi, Guru 
Nanak visited the Majnu.He camped in a garden near Chandrawal and preached his message of love and humanity. A rumors was heard that Nanak had brought a dead elephant back to life. When SikanderLodhi heard about it, he called on Nanak to make a dead elephant of his breath again. When Nanak refused the furious Sultan put him behind the bars. The guards of the Sultan told him the spiritual superiority of the Guru. Exactly at same time a great earth quake shook Delhi. Tall buildings collapsed. The terrified Sultan released the Guru. During the reign of Mohammed ShahRangila,Majnu Nanak Shahi Fakir also used to live in that area. Both the Hindus and the Muslims revered him..There were community gatherings.

On her search to SantokhSingh, the rickshaw driver, the author came across a mansion where Ghalib had lived. Mahesh one of her students accompanied her. The building was not in good condition. The floor slabs were missing. It is said that he wrote poems for both Muslims and Hindus and English rulers. Out of curiosity she asked for the Ghalib's dresses There was no answer. She also read that there was no end to the Ghalib'stroubls..Hehad written an account of the 1857 in Persian.. It was named as “ Dastambu” It was not published by the British even though Ghalib earnestly desired..They climbed up the terrace through a narrow stair case.She thought, it was from that particular point the Ghalib would have witnessed the atrocities continued during 1857. She also had learnt that the Ghalib was so conscious of his self-respect. He resigned his post of a lecturer of Persian in Delhi College because the Secretary Thompson didn't come out to the gate to greet him.

Her historical document would not have been completed without the help of the four Sikh people whom she come across in Delhi In one way or other.Their characters are interrelated with the incidents that happened in and around Delhi. The sikh Baba who never speaks aroused her curiosity. Later she learnt that his daughter was raped and brutally murdered. From that day onwards he never speaks. She understood the horror behind his silence. She learnt that thousands of people had migrated from Dera Ismail Khan but only seventy people escaped the bullets and swords. The Sikh Baba keeps the money of Balbir Singh, thekabadiwala. The author's courtesy towards Balbir made him to keep his carton boxes at her balcony. Though he was an old paperwala he used to do the odd jobs for her. He never expected money from her But the kind lady offered him tea whenever he comes. The author is benefitted by him at his narration of interesting stories about various historical monuments. She carefully recorded them in her note. His son Sonnu a boy of twelve helped his father at his heavy work. Once the author asked him about his schooling Balbir answered bitterly 
"I have severe backache today. Anyhow, you have to first feed the raging fire in the pit of your stomach and then worry about the other things"(14)

One day he informed her that his dear son, died of consumption .It may be his habit of turning the pages of the old books by putting his saliva dipped finger while reading. He trusted the author so much and compelled her to keep his earnings in two cigar boxes till he asked for it. Through Balbirsingh she came to know that his people equated Bhindran wale the founder of the "MORCHA" with Guru Arjun singh.He said that Bhindranwale chant the Guru Granth Sahib better than any one. One day Balbir came to her house .He was nearly dried up. His eyes have sunk in. The author thought his business trip to Faridkot completely changed him. He brought two big boxes to keep under the author's custody. She asked him if he need the money from the cigar box. He requested the author to keep it till the right time. She was shocked when he opened the box because they were filled with currencies. She refused stubbornly. Her heart ached after sending Balbir away. She didn't meet him after that.

Santokh Singh Ajnabi the auto driver is another interesting character who helped the author in her pursuit. She usually went to the university by three wheeler. He was strikingly good looking He reminded the author of the famous artist Shoba Singh's portrait of Sohini-Mahiwal.She also learnt that most of the Sikhs were large hearted people, ready to give their life for friendship. Santokhsngh was eager to know about the author, but she was Cautious of the people of Delhi. He eagerly waited for the author by not allowing others to get in to his vehicle. When the author sits in the rear seat, he used to watch her with curiosity. The author has a strange urge inside her to study men, so that she can portray them correctly in her novels. But in the case of SantokhSingh she felt a kind of sexual desire surging up inside. And tried to control herself..Shesaid.”I feel a sexual desire surging up in side. Ashamed I restrain it immediately."(p 16)To curtail her thoughts she called him brother. She also learnt his love-soaked gaze has turned dry as a desert. One night Santokh Singh came to her corridor wet and disheveled. He rushed inside and asked for five hundred rupees because he hit a cyclist and the police compelled him to pay the amount. The author's anger knew no bounds. The smell of wet clothes and the stench of liquor grew stronger. She said

"Even if my own brother had come so in night, stinking of liquor ,I wouldn't have given him a single paisa"(p 29)

Once she planned to collect material for her book from the sex workers of G.B Road the whores colony. Her university friend Kaikaus told her to go with the 
police. She thought that such arrangement would be impossible for her. She sought the help of Santokh Singh. One Gurupurnima day she went to G.B. Road with SantokhSingh.He had to show all his papers at the police check post. He dropped her at house no.42 and waited for the author. She was threatened by a huge man .She tripped and fell down and her elbow was bleeding. Santokh shouted,

"Ai you whores! How would you know the difference between good and bad? And you scoundrals1 come down! I will teach you a lesson."

With his help she was able to collect some materials. She was confused whethershe was exploiting Santokh Singh by taking advantage of his feelings. She felt a sense of regret On his return Santokh Singh took her in ridge jungles and stopped his vehicle abruptly. He compelled her to get down from the auto barely three kilometers away. As he promised to keep a watch, he climbed at a tower and watched the author. She felt as if she had wrapped around her a blanket made of Santokhsingh.Later she searched for Santokh Singh and Balbir Singh in the refugee camps out of fear and sympathy.Just like Balbir Singh, Santokh Singh also vanished without trace.Brigadier RatanMansingh is another Sikh who accompanied the author in her pursuit. She met him at the Calcutta air port. He resembled Burt Lancaster the American actor. He helped her to get a retiring room when she missed the connecting flight. He met the author at her home with a bouquet..One day an old cobbler in the neighbourhood brought three boys with their parents They were in utter poverty but all are matriculates. They tried their job in army but failed. They requested her to put a word to the brigadier for their job. Whenever he crosses the slum children and youngsters followed him. The Brigadier frequently contacted her through phone. They visited several places. One day SantokhSingh came and revealed that the Brigadier has got money from the poor people for the job. There after she closed her door to avoid such people. During "Operation Bluestar' the author started to worry about Brigadier Mansingh as she did with Balbir and Santpokhsingh. Brigadier Mansingh had called two days earlier.He was leaving for Siachen.Like other three singhs he too vanished suddenly.

Peace is described as a state of free from war or violence. It also refers a state of friendship or harmony. So far the author has experienced peace in around Delhi. The violence she understood was from historical documents or from tell tale stories. The author gives a hint of violence by quoting an incident from "Sepoy Mutiny" narrated by BrigadierBritish forces captured Badshah Bag at Lucknow. They captured a rebel youth. They grilled him alive like a chicken. His skin peeled off like a burnt cloth. He died. In chapter four,Balbir Singh talks about the terrorist 
Satnam Singh alias Chinni.Satnam. He had become the chief of the Bhindranwale Tiger Force of Khalistan.As he was engaging himself in so many killing activities. the Government has announced twenty lakh rupees for his head He was finally shot dead. The hatred of the terrorist started right from pre-Independent period. Since the period of the British ,the Sikhs demanded for a separate nation named Khalistan.During the Freedom struggle Movement, their sacrifice was immeasurable and the leading political leaders promised to fulfill their demands. But after Independence their demands were ignored and they were humiliated. So they launched a 'Morcha'. The bravery and the sacrifice of the Sikhs were not taken in to consideration. These facts have given way to form terrorist groups gradually. Lacey the famous Psychologist argues "Those people who both experience and feel they have experienced humiliation the most acutely are the most likely to resort to violence and aggression."

On 24 $4^{\text {th }}$ April 1983,the country was in turmoil. The Director General of Police in Punjab ,Attwal, was shot dead by terrorists the previous day on the steps of the Golden Temple. The body lay riddled with bullets. The personal security guards of the Director General fled to safety. The Police Commissioner and the granthi of the gurudwara had argued about handing over the body while flies swarmed over the coprse.Police checking had intensified on the streets and lanes of Delhi .Sikhs were forced to get down from buses at Sarai Rohilla,RaniJohnsi Marg, Kingsway Camp and many other places and searched. It caused the sudden disappearance of many Sikhs including Balbir Singh and Santokhsingh.Balbir's sudden arrival to the author's house with carton boxes full of currencies proves that huge sum of money is circulated for terrorist activities.Many shops were closed. and extremists had been killed. SantLongowal and G.S.Tohra had surrendered.There was great agitation and restlessness.

Loot arson rape and murder has become the order of the day in Punjab. Many innocent Sikhs have left Delhi out of fear of the Police. On $4^{\text {th }}$ June 1984 the army has entered the Golden On 28th June some of the university friends called on the On $2^{\text {nd }}$ June news paper reports stated that the situation in the Golden Temple had worsened. Sand bags were piled high all around. The army occupied balconies of houses in the area. The war hardened. The author heard that General Ranjith Singh DayalGOC, Western Command would go to Punjab as Security advisor to the state government. Twenty two months since the foundation of the AkaliMorcha many Sikhs were also killed. Some eleven hundred people were seriously injured and many Morcha were killed. The ominous shadow of murder and destruction in Punjab spreads over Delhi like the shadow cast by vultures on a corpse In the 
Golden Temple Campus. The mission had been named OPERATION BLUE STAR .The author and university friend glued to their television. Sixty army personnel and two hundred But the body of Jarnail Singh Bhindranwale could not be traced among the dead. For a whole week the author's notebook recorded tales of death and killing alone. Killing and marauding went on for a whole week. The bullet riddled body of Bhindranwale was ultimately recovered from the basement of the Akal Takh.The body was hurriedly cremated. The suppressed anger of the Sikhs reflected even in Delhi. All the shops owned by the Sikhs were remained author. At the same moment Santokh Singh visited there. The author enquired about his sudden indifference at MajnukaTila. She also expressed it was due to her courtesy towards her fellow human beings especially the Sikh people whom she come across. She had learnt that many university students had gone under ground terrorist works. The supporters of theAkali Dal, Bhindranwale, of the Longowal group and the Badal-Tohra faction had been arrested. When he talked about Bhindranwale he roared like an angry tiger and said "His back was riddled with bullets , not his chest."(113)

The author was busy in her academic work. She reached the tutorial building at 9.50 am .Then suddenly she heard an out cry from below, "They've killed Indira Gandhi!'”Indira Gandhi murdered?" (p 130)While returning home the author felt the unusual silence was ominous and disturbing. When she reached the golchakkar near the Roshanara Road Police station suddenly a turban rolled in to the road. Someone pushed a Sikh gentleman out of the bus.His spectacles lay scattered near her feet .She was taken aback. Later he was helped by some people. Some called" police !Police!'There was no response. She saw two more turbans on the road at the Sakthinagar crossing and stains of blood like dried pan juice. The house owner Madan Bhaisahab requested her to vacate her room and occupy the nextone. She understood the difficult situation and did so. Instead her room was filled with all sorts of available weapons. Two mattresses were also laid at one end of the room. She understood that self help alone could save them and not the police. She saw the Sikh baba yelling as "Dead bodies are lying in your houses. Has your blood turned white? Why don't you do something?"(133) She witnessed a horrible scene. A Sikh cyclist was burnt alive in the middle of the road all of a sudden. The author said' A heart -rendering cry seems to split the sky into two."(133) One from each house agreed to safe guard their building The author spent sleepless nights. At midnight she heard a knock at the door. When she opened she saw some seven or eight Sikhs and two of them were severely wounded. in a moment the floor of the corridor was wet with blood. A stale smell spread all over the room. She went near them to recognize if Balbir Singh or SantokhSingh were there. But they were all Sikh drivers from 
NagiaPark..Suddenly someone threw brick at their dark house followed by defening shouts, "Blood for Blood. Long live Indira Gandhi!'(137)A stone landed on the author's dressing table. All her cosmetics scattered on the floor. The angry mob roared as

"khoonkabadlakhoon se..."

“...Indira Gandhi zindabad."

"Bring out the traitors..."(138)

Madan Bhaisahab goes out to the balcony and shouts from there, "There is no one here."Again there is a shout, "Bring out the traitors... you have hidden them.".."

Her note book kept on a corner table fell down on the sticky matter. It was too dark to see what was on the floor. The truck moved towards Nagia Park and they all had sighs of relief. Huge explosions rocked their building.Dr.Monga's clinic had been razed to the ground. The author learnt that Dr.Monga had built the hospital with great care and sacrifice. The author slipped and tumbled over in to the corridor Suddenly lights came on and she saw that it was blood that she slipped on .The sight and smell of the blood made her head reel. +"For the first time in my life ,I am mopping up blood and that too by the bucketful. ... I feel a surge of strength while washing away the blood. I think in times of such crises, people rise to their full potential and regain courage and will."(p140) The injured were carefully attended by Madan Bhaisahab's, Nepali servants. In the morning they rushed to the hospital. Her notebook fallen from the table was also soaked in blood. People crowded before Dr.Monga's house. A sweeper was sweeping a side lane. The author saw a pile, a heap of long hair and beard wrenched from the heads and faces of the Sikhs. Suddenly he stopped cleaning because he saw half burnt human jaw with its two rows of teeth and a hump of human flesh. The Sikhs shops had been looted by the slum boys and goondas and also by some hard hearted people. They found no policemen and no army.Every thing happened in broad day light. Three big Sikh establishments had been looted. The body of Indira Gandhi was kept at Teen MurthiBhavan. A group of rowdy mourners who had come to pay their homage to Indira Gandhi set fires to many houses on Lhodi Road at Shahdara. Nearly twenty four Sikhs have tyres put round their necks and burnt to death in broad day light .It was difficult to count the exact number of death because so many bodies were lying in roads and gutters. The Singh Sabha Gurudwara was reduced to ashes.. A truck appeared with two guards with guns in their hands and women in white dress got down. A few well built men also got down. They collected the signed leaves of Granth Sahib most respectfully. They said in unison, 
"Please forgive those who have insulted you. This is our earnest prayer. They also sang "Man is born through the light of God .The same radiance pervades the world. Who then is good or bad?"(p146)The author had been searching for Balbir'sfamily.MadanBhaisahab provided her with a car and driver. One of the boy escorted her whispered."They have eleven women here, widowed in the riots! These ladies were dragged out and made to see their husbands burn"(p 149) The collective number of widows and their sighs touched the author's heart. On $13^{\text {th }}$ November 1984 Indira Gandhi's ashes had been scattered over the. The refugees were compelled to go back to their houses But most of them refused because nothing was left behind at their homes and women still had the fear of raping.

At last the author found BalbirRaddiwala's wife and her son Sonnu sleeping. When the author handed over the money to Blair's wife she humbly refused it because her husband had told nothing about it, The author tried to witness Sonnu for he visited her home several times. The boy's eyes were pierced The author could not bear the sight. She also requested the author to take away those boxes as she could not keep. On her way to home she saw corpses strewn all over the city. The game between the vultures and the dead cattle had begun..Thehalf hearted activities of the corporation workers left everybody disgruntled.The balconies of half burnt houses hung like beehives

The author was rudely awakened by a commotion outside. There was a dead body at the goal chakkar.It was brutally chopped At last the author identified that it was the body of Santokh Singh The earth seemed to slip under the feet of the author.Kaikaus helped her. It is said that he involved in clandestine arms making, fell out with some militant groups and ultimately met with his fate. There were details of how a Political Dada lifted bus loads of people from sheikh Sarai and Muniraka to plunder and kill. There were also detailed description of destructions at a school in Trilokpuri. No one was at A T Block. In the Teen Hazari Mortuary some two hundred corpses came from A T Block alone. A journalist prepared a book contained names and address of leaders ,bosses, merchants,gundas and butchers who were responsible for the cornage.That book was latter seized from all book shopThe killing of Santokh Singh and the disappearance of Balbir Singh disturbed the author very much. Her desire to write a book on Delhi with itscolourful vision was gone. When media persons questioned about the riots, the son of the late prime minister replied as"When great trees fall the earth shakes". The simple answer could not wash away the blood stains, pains and pangs of the Sikh Community. It is unfair to put iron hands on innocent, helpless ladies and children who are far away from the clandestine. Thehalf 
hearted rescue operations of the local officials had left adeep scar in the peoples mind. Hence the author titled her novel as "PAGES STAINED WITH BLOOD." According to the author the world is tied with unknown bonds of humanity, love ,sympathy, kindness, curtesy and tolerance. A small misunderstanding can lead to worst consequences. She said Upendra Chandra Lekharu her teacher inspired her very much.

"My teacher inspired me to be neither a famous writer nor an eminent scholar, but an individual endowed with all human qualities. Nothing measures up to humanity.For my teacher, humanity alone was the prime consideration, and nothing else..."The author's novel is an outpour of her humanity and nothing else.She never exaggerated any where. Her writing reflects her genuine attempt to revealthe genocide.

\section{References}

1.Goswami, Indira.Pages Stained With Blood translated by PradipAcharya. NewDelhi; Katha Publishers 2002

2 Das, Veena. “Indian Women. Work, Power And Status. ”New Delhi; Prestige Publishers1976.

3.Satyanath.T.S "Reading through the Pages Stained with Blood" Indian Literature(July, Aug 2012):68-69 .

4.Burjror Satarawala,Kaikous. "Her fictional world" The search for the sea. Delhi;B.R Publishing Corporatio.2002

5.Gogi,Haridayananda. “Dr.IndiraGoswami In Search Of Modernity. ’Delhi: B.R Publishing Corporation 2002.

6.Bala, Suman. "Indira Goswami's The Saga of Kamrup; A Study Indian Women Novelist; Set III;VOL 6. R .K.Dhawan(Ed)New D elhi; Prestige Books ,1995.

7.Baruah, Manjeet. Indira Goswami, A Compilation on her Life, Works Achievements. Delhi;B.R Publishing Corporation.2007.

8. Kotoky, Prafulla. "Selected Works of Indira Goswami, New World Literature Series;12” Delhi B. R. Publishing Corporation.1998.

9.Subbamma, Malladi, "Women ,Tradition and Culture" New Delhi; Sterling Publisher Private Ltd., $1^{\text {st }}$ May 1985.

10. Edward, Philip “Pilgrimage And Literary Tradition."; Cambridge University Press $3^{\text {rd }}$ December..2009

11.Grewal,J.S , "Love and Gender In the Rig-Veda and Medieval Punjabi Literature" 
12.Goswami,Indira. “Anunfinished Autobiography”,Translated by P.Kotoky. NewDelhi: Sterling Publisher(P) Ltd.,2002.

\section{Sources}

1. http//www.amazoncastle.com/feminism

2. www.politicalsciencenotes.com/articals/feminismin politics-definition-developmenttypes

3. Didion,Joan"without Regret or Hope".New York Review of Books,web.12 june 2009http://www.ny books. com/articles/7366

4. Web 04.june 2008.<http;//en.wikipedia.org/wiki/travel-literature> 